The OECD Environmental Performance Review of the United States

\section{U.S. Environmental Performance Is Improving, But Work Remains}

\author{
Die Nachhaltigkeitsberichterstattung gewinnt auch auf interna- \\ tionaler Ebene zunehmend an Bedeutung. Die Bewertung der \\ US-Umweltpolitik durch die OECD hält dabei einige Überra- \\ schungen bereit. Von Miranda Schreurs
}

$T^{-1}$ en years after the Organization for Economic Cooperation (OECD) issued its first Environmental Performance Review (EPR) of the United States the second evaluation of the country's environmental programs, policies, and outcomes was released this year. The 284-page EPR is broad in coverage and relatively tame in its conclusions. Environmentalists are likely to be disappointed by the report's mild tone; industry is likely to be encouraged by the report's findings of substantial progress in the U.S. at decoupling environmental outcomes from economic growth. The United States government appears pleased with the report's conclusion. The Department of State has already posted information about the report on its website: "The United States has improved its environmental performance in the past eight years, even as its economy and population have grown, says a report from the Environmental Performance Review Program" of the international OECD. "The report documents, for example, that from 1996 to 2005, the United States reduced pollution during a period when there was a ten percent increase in the size of the population and a 30 percent increase in the nation's gross domestic product." (1)

\section{Achievements and need of improvement}

The report finds much to praise about U.S. environmental achievements. It points out that emissions of carbon mo- noxide, lead, nitrogen oxides, sulfur dioxide, particulate matter, and volatile organic compounds were "strongly decoupled" from economic growth and links these developments to the effects of the U.S. Clean Air Act and the introduction of market-based instruments and voluntary measures (p. 34). It speaks positively about the shift in the U.S. towards greater flexibility for states in how they fulfill federal requirements and it notes that the U.S. Clean Air Act has been one of the most successful pieces of legislation from a cost-benefit perspective. It singles out the United States as a global leader in climate change science and a pioneer in the introduction of market-based instruments.

The OECD team did find substantial areas in need of improvement, however. Air pollution intensities for many common pollutants, for example, remain rather high compared with other OECD countries and pose human health risks. An estimated 160 million individuals live in areas that are in non-attainment for ozone and/or particulate matter. Infant death rates are higher in the U.S. than in other G-7 countries, and chronic diseases, some caused by or aggravated by environmental factors, are on the rise. Risks from exposure to indoor air pollutants is quite high among some groups, particularly school children. Furthermore, the U.S. is the world's largest consumer of energy and contributor to global greenhouse gas emissions.

Many of the problem areas the EPR identified are linked to U.S. energy con- sumption patterns and lack of forceful policy leadership in reducing reliance on fossil fuels as suggested by the fact that there were no changes made to the Corporate Average Fuel Economy standards for passenger cars during the review period. Others are tied to the failure to consistently apply the polluter pays and user pays principle, e.g. for water and energy use, which if applied could reduce demand for these resources. Yet others are tied to broader, problematic societal trends, including growing poverty and health problems. Interestingly, the report pays considerable attention to environmental conditions on Indian reservations.

\section{A broad report but lacks in depth}

In part because the report tries to cover so much, it has difficulty doing issues justice. In reading about U.S. approaches to climate change, for example, one is left desiring greater discussion as to why several U.S. states and municipalities have felt it necessary to take the lead in climate change policies and programs. Moreover, one is left thinking there should be at least some mention made of the efforts by the automobile industry to prevent the enforcement of California's carbon dioxide emission reduction requirements. There are also a variety of issues that do not get covered by the report, such as the consumption-environment-waste relationship or noise-related pollution. Reader of the report should also be aware that in some places the report is already dated. This if, for instance, the case with the discussion of energy policy given that the Energy Policy Act of 2005 was passed only after work on the report had been concluded. The report also does not mention U.S. opposition to European efforts to promote REACH, (Registration, Evaluation, and Authorization for Chemicals) in its discussion of U.S. cooperation on chemicals management.

Of the 51 recommendations that the team generated, many are quite general and basically suggest that the U.S. government continue to do what it has already started to do in recent years: expand use 
of incentives to promote voluntary wildlife conservation and co-operative conservation approaches through voluntary partnerships; strengthen management of protected areas and persist with newly initiated efforts to strengthen coastal and marine protection, wetland protection and restoration efforts; make urban development more sustainable through approaches such as EPA's Smart Growth program, redevelopment of brownfields, and urban environmental programs.

Others adopt the cost-benefit language which has come to be favored by industrial interests and many in government. This language emphasizes weighing the economic costs of proposed measures with their presumed environmental benefits in order to rationalize environmental legislation. Critics of the cost-benefit analysis approach tend to raise the environmental justice concerns that frequently remain when cost-benefit analyses are applied to environmental problems. Thus, the report recommends implementing a "cost-effective national system to achieve targeted reductions of emissions from existing power stations" (p. 34). (2) It also calls for expanding the role of marketbased instruments in order to increase cost-effectiveness and economic efficiency in environmental management.

While the report's 51 recommendations may not be earth-shattering, many of them, if adopted by the U.S. government could do much to further strengthen U.S. environmental performance or improve its international environmental image. Examples include the recommendations to revitalize Corporate Average Fuel Economy standards for motor vehicles; to make greater use of economic instruments in the transport sector that would benefit the environment, such as road pricing, fuel taxation, and incentives to purchase fuel-efficient and low-emission vehicles and fuels; to review government financial assistance, including subsidies, preferential loans, and tax incentives, for the provision of environmental services so that it better takes into account the polluter pays and user pays principles; to expedite ratification of international environmental agreements that the U.S. has signed, like the Stockholm Convention on Persistent Organic Pollutants or the Convention on Biological Diversity.

\section{Environmental Performance Reviews - A meaningful monitoring tool?}

In an article addressing OECD Environmental Performance Reviews, Markku Lehtonen, who was himself a reviewer for several other OECD EPRs, notes that a problem with most EPRs is that they tend to be too cumbersome to read as they are written in impersonal and technical language. Their conclusions, moreover, typically are written in such a way as to win the confidence, trust, and support from the national governments that are being reviewed. As a result, the recommendations tend to be written in "soft, consensual, diplomatic, and general" terms that fail to elicit desired public debate. (3) Lehtonen's general assessment of OECD EPRs applies to the US EPR as well.

The OECD EPRs do have a role to play, even if there are many ways in which they can be criticized for their short comings. The mere fact that an external organization has committed to regular evaluations of performance should place a certain pressure on national governments to show improvements over time. Thus, while the U.S. government can bask in the international recognition of its environmental accomplishments, it must also face up to some rather harsh critiques of its policy performance, such as in relation to pollution-related health problems. Moreover, the report is a valuable tool for conducting cross-temporal and cross-national comparisons within and among countries that have been reviewed by the organization and can aid in efforts to systematize data collection over time. Finally, this is but one of a growing number of systematic, cross-national efforts to evaluate countries' environmental and sustainability performance. Other efforts include the Environmental Performance Index, which ranked the U.S. 28th among nations in its performance level or the Environment Sustainability Index, which ranked the U.S. 45th. Taken together these kinds of evaluation tools can be very important for applying pressure on governments and citizens to strengthen their performance.

The value of the report might be greater if the overall number of recommendations were reduced. Fifty-one recommendations seems to be a lot to focus attention on. The potential to collapse recommendations is certainly there. In many of the chapters were recommendations for greater coordination and cooperation among agencies and between federal and state agencies in policy creation and enforcement. Thus, for example, there are at least three separate recommendations calling for: 1.) ensuring that federal and state enforcement activities for air quality management are well-coordinated, 2 .) improving co-ordination and co-operation in establishing federal water objectives and policies, and 3.) emphasizing coherence and co-operation among federal agencies and between federal and state bodies concerned with environmental management.

Policy makers, or at least their staff, might be more likely to pay attention to the report if it made more specific and innovative policy recommendations.

\section{Notes}

(1) Cheryl Pellerin, “U.S. Has Improved Environmental Performance, Panel Says: International review shows substantial gains, suggests improvements," January 10, 2006,

http://usinfo.state.gov/gi/Archive/2006/Jan/1 1-210449.html

(2) It is interesting to note that carbon dioxide is absent from the list of air pollutants $\left(\mathrm{SO}_{x}, \mathrm{NO}_{\mathrm{x}}\right.$ and mercury) referenced; this has been a matter of considerable debate in the U.S. Congress.

(3) Markku Lehtonen, "OECD Environmental Performance Review Programme: Accountability (f)or Learning?" Evaluation, Vol 11 (2): 169-88, quotation from p. 182.

\section{AUTORIN + KONTAKT}

Miranda Schreurs ist Associate Professor an der Abteilung Regierung und Politik der University of Maryland.

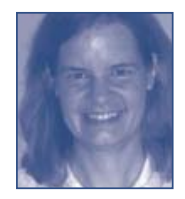

Department of Government

and Politics, 3140 Tydings Hall, University of Maryland, College Park, MD 20742, USA. Tel.: +001/301/405-7797, Fax: $+001 / 301 / 314-9690$,

E-Mail: mschreurs@gvpt.umd.edu 
(c) 20I0 Authors; licensee IÖW and oekom verlag. This is an article distributed under the terms of the Creative Commons Attribution Non-Commercial No Derivates License (http://creativecommons.org/licenses/by-nc-nd/3.o/), which permits unrestricted use, distribution, and reproduction in any medium, provided the original work is properly cited. 